\title{
Mutation analysis of the chromosome 14q24.3 dihydrolipoyl succinyltransferase (DLST) gene in patients with early-onset Alzheimer disease
}

\author{
Marc Cruts ${ }^{a}$, Hubert Backhovens ${ }^{a}$, Geert Van Gassena, Jessie Theuns ${ }^{a}$, Sheng-Yue Wanga, \\ Anita Wehnerta ${ }^{a}$, Cornelia M. van Duijn ${ }^{b}$, Thomas Karlsson ${ }^{c}$, Albert Hofman ${ }^{b}$, \\ Rolf Adolfssonc, Jean-Jacques Martin ${ }^{\mathrm{d}}$, Christine Van Broeckhovena,* \\ ${ }^{a}$ Laboratory of Neurogenetics, Born-Bunge Foundation, University of Antwerp (UIA), Department of Biochemistry, Universiteitsplein 1, \\ B-2610 Antwerpen, Belgium \\ bepartment of Epidemiology and Biostatistics, Erasmus University Medical School, 3000 DR Rotterdam, The Netherlands \\ ${ }^{c}$ Department of Psychiatry, University of Umed, S-901 85 Umed, Sweden \\ ${ }^{\mathrm{d}}$ Laboratory of Neuropathology, Born-Bunge Foundation, University of Antwerp (UIA), Department of Medicine, B-2610 Antwerpen, Belgium
}

Received 21 June 1995; revised version received 28 August 1995; accepted 28 August 1995

\begin{abstract}
Linkage analysis studies have indicated that the chromosome band $14 \mathrm{q} 24.3$ harbours a major gene for familial early-onset Alzheimer's disease (AD). Recently we localized the chromosome $14 \mathrm{AD}$ gene (AD3) in the $6.4 \mathrm{cM}$ interval between the markers D14S289 and D14S61. We mapped the gene encoding dihydrolipoyl succinyltransferase (DLST), the E2k component of human $\alpha$ ketoglutarate dehydrogenase complex (KGDHC), in the AD3 candidate region using yeast artificial chromosomes (YACs). The DLST gene is a candidate for the AD3 gene since deficiencies in KGDHC activity have been observed in brain tissue and fibroblasts of AD patients. The 15 exons and the promoter region of the DLST gene were analysed for mutations in chromosome 14 linked AD cases and in two series of unrelated early-onset $A D$ cases (onset age $<55$ years). Sequence variations in intronic sequences (introns 3,5 and 10 ) or silent mutations in exonic sequences (exons 8 and 14) were identified. However, no AD related mutations were observed, suggesting that the DLST gene is not the chromosome $14 \mathrm{AD} 3$ gene.
\end{abstract}

Keywords: Alzheimer disease; Alpha-ketoglutarate dehydrogenase complex; KGDHC; E2k component; Dihydrolipoyl succinyltransferase gene; DLST; chromosome 14; Mutation analysis; Polymorphisms

A genome-wide search has resulted in the localization of a gene for familial early-onset Alzheimer's disease (AD) on chromosome $14 \mathrm{q} 24.3$ in an interval of $22.7 \mathrm{cM}$ between the markers D14S52 and D14S53 [19]. Chromosome 14 linkage of early-onset AD was also found independently by three other groups $[16,21,22]$. Since these initial chromosome 14 linkage reports many other investigators have reported linkage to chromosome 14 in their families $[4,8,15,23]$, indicating that the chromosome 14 gene is a major gene for familial early-onset AD. More recently, we were able to reduce substantially the size of the candidate region for the chromosome $14 \mathrm{AD}$ gene (AD3) based on informative recombinants in the two

\footnotetext{
* Corresponding author. Tel. +3238202601 ; fax: +3238202541 .
}

Belgian chromosome 14 linked early-onset $\mathrm{AD}$ families $\mathrm{AD} / \mathrm{A}$ and $\mathrm{AD} / \mathrm{B}$ [7]. The $\mathrm{AD} 3$ was localized between the markers D14S289 and D14S61, a region of $6.4 \mathrm{cM}$ on the integrated genetic map of chromosome 14 [3]. Also, we constructed a physical map of the AD3 candidate region consisting of overlapping yeast artificial chromosomes (YACs) and estimated that the size of the AD3 candidate region is between 2 and $6 \mathrm{Mb}[5,7]$. The YAC contig map was used to map known genes that were previously assigned to chromosome 14 using different mapping methods. Three genes mapped within the AD3 candidate region, i.e. the cellular oncogene c-fos (FOS), the transforming growth factor $\beta 3$ gene (TGFB3) and the dihydrolipoyl succinyltransferase gene (DLST) [5,7]. FOS has been excluded as the AD3 gene since sequence analyses 
Table 1

Primer sequences used in the SSCP analysis and sequencing of DLST

\begin{tabular}{|c|c|c|c|c|}
\hline Region & Primer & Position & Sequence & Size \\
\hline \multirow[t]{3}{*}{ Promoter } & E2k-3 & -649 to -629 & AGTTTGGCTGGAATTTGCGTT & 462 \\
\hline & E2k-4 & -188 to -210 & GAGGTGGTTCTCCTGAAGGTGTA & \\
\hline & E2k-52 & -645 to -627 & TGGCTGGAATTTGCGTTGG & (Sequencing primer) \\
\hline \multirow[t]{2}{*}{ Exon 1} & E2k-19 & -71 to -55 & AGTGGTTCGCTCCGAAC & 223 \\
\hline & E2k-20 & $151-135$ & AACAGACTCCTCACCCG & \\
\hline \multirow[t]{2}{*}{ Exon 2} & E2k-21 & $543-565$ & GTTGCATTTACTTCGGAGTTACG & 310 \\
\hline & $\mathrm{E} 2 \mathrm{k}-22$ & $852-831$ & CGTGATTATGTAGCATTGCGTC & \\
\hline \multirow[t]{2}{*}{ Exon 3} & $\mathrm{E} 2 \mathrm{k}-23$ & $3540-3559$ & TATATCCGTTGCCGTTGATC & 231 \\
\hline & E2k-24 & $3770-3744$ & CTTTATGTCTTTAAATAATAACCCGTG & \\
\hline \multirow[t]{2}{*}{ Exon 4} & E2k-25 & $7116-7134$ & AAATGTGAGTGGTTCGCCT & 280 \\
\hline & E2k-26 & $7395-7376$ & TGACAGATTCTGCAAACGCT & \\
\hline \multirow[t]{2}{*}{ Exon 5} & E2k-27 & $7250-7273$ & TTTATGGGAAGAGCAACAATTGAT & 306 \\
\hline & E2k-30 & $7494-7475$ & ACTCCAGGCTGGGAACAGAG & \\
\hline \multirow[t]{2}{*}{ Exon 6} & E2k-5 & $7847-7870$ & CATATGTACTTTCTGCTGGCCCTG & 220 \\
\hline & E2k-6 & $8066-8043$ & AAGCCCATGAAAAGCTGGTACGAA & \\
\hline \multirow[t]{2}{*}{ Intron 6} & E2k-17 & $8669-8692$ & GAAGTGAATCTTCACAGCTAGCGA & 207 \\
\hline & E2k-18 & $8875-8856$ & GGCAGGTGGAGCCATATCGT & \\
\hline \multirow[t]{2}{*}{ Exon 7} & E2k-7 & $8995-9016$ & GTGATCCGCCTGCCTTGGCATC & 296 \\
\hline & E2k-8 & $9292-9267$ & GAGGGAACACTGGAGACCTTGACCAC & \\
\hline \multirow[t]{2}{*}{ Exon 8} & E2k-9 & $10793-10815$ & GCTGATACCCAGTAGACATTCGT & 334 \\
\hline & $\mathrm{E} 2 \mathrm{k}-10$ & $11126-11102$ & CCTTTGAAGGAACATATTAGACGAG & \\
\hline \multirow[t]{2}{*}{ Exon 9} & E2k-15 & $11327-11353$ & CTTGAAGATTAAGTAACAGTACATATG & 266 \\
\hline & E2k-16 & $11592-11569$ & CATTCAAAGGTAGGCTACACCACA & \\
\hline \multirow[t]{2}{*}{ Exon 10} & E2k-31 & $12293-12312$ & ATCTACTCGTGGCAAGCCGT & 266 \\
\hline & E2k-32 & $12558-12537$ & ATAAGGAGTGGGGCAAGTTCGT & \\
\hline \multirow[t]{2}{*}{ Exon 11} & E2k-33 & $16360-16385$ & CACCTAACTTGTGTATATGGATTGAG & 285 \\
\hline & E2k-34 & $16644-16622$ & GGAGCAGGTCTGTGCTCATACAC & \\
\hline \multirow[t]{2}{*}{ Exon 12} & E2k-35 & $17939-17964$ & ATATTACCTCATTAGTCTTGGCCTTC & 339 \\
\hline & $\mathrm{E} 2 \mathrm{k}-36$ & $18277-18252$ & CTAGAATACCTTCATTACTCAGTGTG & \\
\hline \multirow[t]{2}{*}{ Exon 13} & E2k-37 & $18293-18317$ & GGTTGAATTCAAGGGAGTTGTTAAC & 260 \\
\hline & $\mathrm{E} 2 \mathrm{k}-38$ & $18552-18530$ & ACTTGACTTTCCATGAGCACTGC & \\
\hline \multirow[t]{3}{*}{ Exon 14} & E2k-39 & $19056-19071$ & TCGGCCTCCCAAAGCG & 288 \\
\hline & $\mathrm{E} 2 \mathrm{k}-40$ & 19343-19319 & CCACTAGGACCTTAGAAGTGACGGT & \\
\hline & E2k-51 & $19108-19132$ & GGGGTGGCTTAATATTTCAATTATG & (Sequencing primer) \\
\hline \multirow[t]{4}{*}{ Exon 15} & E2k-11 & $20134-20159$ & AATACTGTAAATATGCAGAGCGTAAC & 255 \\
\hline & E2k-12 & $20388-20370$ & TCTGGGATCCTCTACCGCT & \\
\hline & E2k-13 & $20282-20300$ & TGCGGCCCATGATGTACGT & 237 \\
\hline & $\mathrm{E} 2 \mathrm{k}-14$ & $20518-20496$ & ACAGCATGTGTCTGCCTGTCACC & \\
\hline
\end{tabular}

The position of the primers is according to the numbering of Nakano et al. [17] starting at exon 1. The size of the PCR products is indicated in bp. The PCR amplification of $200 \mathrm{ng}$ genomic DNA was performed in a total volume of $25 \mu \mathrm{l}$ according to standard procedures. The PCR sequencing was performed as described in the text. In case of the promoter region and exon 14 , internal primers were designed for sequencing.

did not reveal AD3 related mutations in patients belonging to different chromosome 14 linked early-onset $A D$ families $[2,6,18]$.

The DLST gene which codes for the E2k component of the mitochondrial $\alpha$-ketoglutarate dehydrogenase complex (KGDHC), is a candidate for the AD3 gene because reductions in KGDHC activity have been observed in AD patients. KGDHC is a multicomponent mitochondrial enzyme complex that catalyses the rate-limiting step of oxidative decarboxylation of $\alpha$-ketoglutarate to succinyl-CoA in the tricarboxylic acid cycle. A defect of this enzyme complex could explain the energy metabolism defects observed in brain and fibroblasts of AD patients $[13,20]$. In $\mathrm{AD}$ brain the neuronal degeneration may be explained by excitotoxicity of glutamate, a brain neuro- toxin accumulating because of the KGDHC deficiency [13]. In cultured fibroblasts of both $A D$ and chromosome 14 linked $A D$ patients, immunoblotting identified an abnormality of the E2k component of KGHDC [20]. The DLST gene coding for E2k, was cloned and mapped to chromosome $14 \mathrm{q} 24.3$ by somatic cell hybrid mapping and in situ hybridisation [1]. We used the YAC contig map to localize the DLST gene in the AD3 candidate region between the linked markers D14S43 and D14S284 [5,7].

In this study we performed a mutation analysis of the DLST gene in patients with proven chromosome 14 linked $A D$ and in patients belonging to two series of unrelated $A D$ cases with onset of $A D$ below or at age 55 years. The cut-off age of 55 years was chosen because in the majority of the chromosome 14 linked families the 
mean age at onset is before this age [9]. The AD patients with chromosome 14 linked $A D$ are $A D / A-V 43$ and $\mathrm{AD} / \mathrm{B}-\mathrm{IV} 15$ belonging to families $\mathrm{AD} / \mathrm{A}$ and $\mathrm{AD} / \mathrm{B}$ [22], and two patients of each family FAD1, FAD2 and FAD4 [21], namely AG7647A, AG6849A, AG8526, AG8562A, AG8109A and AG7877 of which cell lines were obtained through the NIA cell repository. The two series of earlyonset $\mathrm{AD}$ patients contained 21 patients with a mean onset age of $50.2 \pm 1.9$ years (range $47-55$ years) obtained in a population-based study of early-onset $A D$ in the area of Rotterdam, The Netherlands [11], and 20 patients with mean onset age of 51.2 \pm 3.3 years (range 45-55 years) clinically ascertained at the University Hospital in Umea, Sweden (Adolfsson et al., unpublished data). Each of the patients received a diagnosis of presenile dementia that fulfilled the NINCDS-ADRDA criteria of probable $A D$ [14]. Also, mutation analysis of exons 16 and 17 of the amyloid precursor protein (APP) gene at chromosome 21q21.2, using both single stranded conformational polymorphism (SSCP) analysis and direct PCR sequencing had not revealed any mutations in these patients ([24]; Adolfsson et al., unpublished data).

First we examined all 15 exons of the DLST gene for mutations by SSCP analysis. For this purpose intronic primers flanking each exon were designed based on the published genomic sequence of the DLST gene [17]. For the larger exon 15, two overlapping primer sets were used. The sequences of each primer pair used in the SSCP analysis are illustrated in Table 1. Each exon was PCR amplified under standard conditions and the PCR products were heat denatured and separated by electrophoresis at room temperature on a $1 \times$ Hydrolink MDE gel (J.T. Baker, Phillipsburg, USA) in the presence or absence of $10 \%$ glycerol. The electrophoresis conditions of $13 \mathrm{~h}$ at $800 \mathrm{~V}$ allowed the analysis in one experiment of both the heteroduplex and SSCP. The DNA fragments were visualized by silver-staining [10]. Clearly altered SSCP patterns were detected when exons 5 and 11 were analysed in the presence of glycerol and exons 8 and 14 in the absence of glycerol. The change in the SSCP pattern of exons 5, 8 , 11 and 14 was the same in each case, suggesting that the same sequence variation was present. Further, the altered SSCP patterns of exons 5, 8, 11 and 14 were present in some but not all of the chromosome 14 linked $\mathrm{AD}$ and early-onset $\mathrm{AD}$ patients. Also, since for each of the exons $5,8,11$ and 14, homozygotes were detected for each SSCP allele, the data suggested that the sequence variations in these exons are polymorphisms and not $\mathrm{AD}$ related mutations. No polymorphic variations were detected for the $(G T T)_{5}$ repeat located in intron 6 [17], when genomic DNA of the 49 AD patients was PCR amplified using primers E2k-17 and E2k-18 (Table 1).

The sequences of exons $5,8,11$ and 14 were determined after PCR amplification of genomic DNA of patients AD/A-V43 and AD/B-IV15, and one escapee, $\mathrm{AD} / \mathrm{A}-\mathrm{V} 30$ and $\mathrm{AD} / \mathrm{B}-\mathrm{IV} 5$, of each of the two Belgian
Table 2

DLST polymorphisms

\begin{tabular}{|c|c|c|c|}
\hline Primers & $\begin{array}{l}\text { Location of } \\
\text { polymorphism }\end{array}$ & $\begin{array}{l}\text { Nucleotide } \\
\text { position }\end{array}$ & $\begin{array}{l}\text { Type of } \\
\text { polymorphism }\end{array}$ \\
\hline $\begin{array}{l}\text { E2k-25, } \\
\text { E2k-26 }\end{array}$ & Intron 3 & 7160 & $C$ insertion \\
\hline $\begin{array}{l}\text { E2k-27, } \\
\text { E2k-30 }\end{array}$ & Intron 5 & 7461 & $(\mathrm{~T})_{\mathrm{n}}$ repeat \\
\hline $\begin{array}{l}E 2 k-9 \\
E 2 k-10\end{array}$ & Exon 8 & 11044 & $G$ to $A$ transition \\
\hline $\begin{array}{l}\text { E2k-31, } \\
\text { E2k-32 }\end{array}$ & Intron 10 & 16439 & $\mathrm{G}$ to $\mathrm{A}$ transition \\
\hline $\begin{array}{l}\text { E2k-39, } \\
\text { E2k-40 }\end{array}$ & Exon 14 & 19183 & $\mathrm{C}$ to $\mathrm{T}$ transition \\
\hline
\end{tabular}

The position of the polymorphisms is according to the numbering of Nakano et al. [17] starting at exon 1.

chromosome 14 linked families $\mathrm{AD} / \mathrm{A}$ and $\mathrm{AD} / \mathrm{B}$ [12]. An escapee was defined as a healthy individual of whom the current age was at least two standard deviations beyond the mean age at onset of 35 years in the family. For sequencing, the PCR products of six identical PCR reactions were pooled and the PCR products were purified by the Spinbind Purification System of FMC (Rockland, USA). The sequences of both strands were determined with the fluorescent $\mathrm{T} 7$ terminator system of Applied Biosystems (Foster City, USA) and were analysed on an automated DNA sequencer model 373A of Applied Biosystems (Foster City, USA). In each case a mutation was found that could explain the altered bands in the SSCP analysis (Table 2). Two of the mutations are intronic sequence variations, a diallelic $(\mathrm{T})_{\mathrm{n}}$-repeat in intron 5 and a transition of $A$ to $G$ in intron 10 . The mutations in exons 8 and 14 are silent mutations at third codon bases at codons 192 and 366, respectively. None of the mutations were $A D$ specific since they were found in both the $A D$ patients and escapees, confirming our previous observation that the altered SSCP patterns represent DLST polymorphisms. The allele frequencies for each DLST polymorphism were calculated from the SSCP results obtained in the whole population of $49 \mathrm{AD}$ patients and were $0.57 / 0.43$ for the intron 5 polymorphism, $0.81 / 0.19$ for the exon 8 polymorphism, $0.46 / 0.54$ for the intron 10 polymorphism and $0.44 / 0.56$ for the exon 14 polymorphism.

Linkage analysis in families $\mathrm{AD} / \mathrm{A}$ and $\mathrm{AD} / \mathrm{B}$ using the exon 14 DLST polymorphism showed complete segregation of DLST with AD. Consequently we sequenced all other 11 exons and the promoter region of DLST (Table 1). No $A D$ related sequence differences were observed. However, one more polymorphism was detected in intron 3 where a $C$ insertion was observed in patient $A D / A-V 43$ and escapee AD/B-IV5 (Table 2).

In conclusion, the mutation analysis of DLST in chromosome 14 linked AD patients and patients with early- 
onset of $\mathrm{AD}$ before or at age 55 years has not revealed mutations that are AD related. In total, five polymorphic sequence variations were detected, three in, respectively, introns 3,5 and 10, and two in, respectively, exons 8 and 14. The latter two polymorphisms, although in coding sequences, do not cause a change at the protein level since they are both silent mutations at third codon bases. The absence of $\mathrm{AD}$ related mutations in the coding region and the promoter of DLST excludes this gene as candidate for AD3.

The authors are grateful to the patients and their families for their co-operation in our research project, to Patrick Cras and Marc Bruyland for help with the clinical diagnoses in families $\mathrm{AD} / \mathrm{A}$ and $\mathrm{AD} / \mathrm{B}$, to Joke De Voecht for technical help in the DNA analysis, and to Hilda Kornman, Jeanette Kamman and Hanneke van Meurs for their help in data collection. This work was in part funded by the Flemish Biotechnology Program of the Ministry of Economy, a concerted action of the Flemish Ministry of Education, and grants to CVB of the National Fund for Scientific Research (NFSR), Belgium, and the American Health Assistance Foundation (AHAF), USA; the Netherlands Organisation for Scientific Research (NWO) and the Netherlands Institute for Health Sciences (NIHES); the Torsten and Ragmar Söderberg, Lars Hierta, Åke Wiberg, and Tore Nilsson Foundations, and the Swedish Medical Research Council. CVB is a research associate of the NFSR, Belgium and GVG and JT are grantholders of the Institute for Science and Technology (IST), Belgium.

[1] Ali, G., Wasco, W., Cai, X., Szabo, P., Sheu, K.-F.R., Cooper, A.J.L., Gaston, S.M., Gusella, J.F., Tanzi, R.E. and Blass, J.P., Isolation, characterization, and mapping of gene encoding dihydrolipoyl succinyltransferase (E2k) of human $\alpha$-ketoglutarate dehydrogenase complex, Somatic Cell Mol. Genet., 20 (1994) 99105.

[2] Bonnycastle, L.L.C., Chang-En, Y., Wijsman, E.M., Orr, H.T., Patterson, D., Clancy, K.P., Goddard, K.A.B., Alonso, M.E., Nemens, E., White, J.A., Heston, L.L., Martin, G.M., Bird, T.D. and Schellenberg, G.D., The c-fos gene and early-onset familial Alzheimer's disease, Neurosci. Lett., 160 (1993) 33-36.

[3] Cox, D.W., Gedde-Dahl, T., Menon, A.G., Nygaard, T.G., Tomlinson, I.M., Peters, J., St George-Hyslop, P.H., Walter, M.A. and Edwards, J.H., Report of the second international workshop on human chromosome 14 mapping, 1994. In A.J. Cuticchia (Ed.), Human Gene Mapping: a Compendium, Johns Hopkins University Press, Baltimore, 1995, pp. 568-581.

[4] Campion, D., Brice, A., Hannequin, D., Tardieu, S., Dubois, B., Calenda, A., Brun, E., Penet, C., Tayot, J., Martinez, M., Bellis, M., Mallet, J., Agid, Y, and Clerget-Darpoux, F., A large pedigree with early-onset Alzheimer's disease: clinical, neuropathological, and genetic characterization, Neurology, (1995) in press.

[5] Clark, R.F., Cruts, M., Korenblat, K.M., Chengshi, H., Talbot, C., Van Broeckhoven, C. and Goate, A.M., A yeast artificial chromosome contig from human chromosome 14q24 spanning the Alzheimer's disease locus AD3, Hum. Mol. Genet., 4 (1995) 13471354.

[6] Cruts, M., Backhovens, H., Martin, J. and Van Broeckhoven, C., Genetic analysis of the cellular oncogene fos in patients with chromosome 14 encoded Alzheimer's disease, Neurosci. Lett., 174 (1994) 97-100.

[7] Cruts, M., Backhovens, H., Theuns, J., Clark, R.F., Le Paslier, D., Weissenbach, J., Goate, A.M., Martin, J. and Van Broeckhoven, C., Genetic and physical characterisation of the early-onset Alzheimer's disease AD3 locus on chromosome 14q24.3, Hum. Mol. Genet., 4 (1995) 1355-1364.

[8] Haltia, M., Viitanen, M., Sulkava, R., Ala-Hurala, V., Poyhonen, M., Goldfarb, L., Brown, P., Levy, E., Houlden, H., Crook, R., Goate, A., Clark, R., Korenblat, K., Pandit, S., Donis-Keller, H., Lilius, L., Liu, L., Axelman, K., Forsell, L., Winblad, B., Lannfelt, L. and Hardy, J., Chromosome 14-encoded Alzheimer's disease: genetic and clinicopathological description, Ann. Neurol., 36 (1994) 362-367.

[9] Hardy, J., Houlden, H., Collinge, J., Kennedy, A., Newman, S., Rossor, M., Lilius, L., Winblad, B., Crook, R. and Duff, K., Apolipoprotein E genotype and Alzheimer's disease, Lancet, 342 (1993) 737-738.

[10] Herring, A.J., Inglis, N.F., Ojeh, C.K., Snodgrass, D.R. and Menzies, J.D., Rapid diagnosis of rotavirus infection by detection of viral nucleic acid in silver-stained polyacrylamide gels, J. Clin. Microbiol., 16 (1982) 473-477.

[11] Hofman, A., Schulte, W., Tanja, T.A., van Duijn, C.M., Haaxma, R., Lameris, A.J., Otten, V.M. and Saan, R.J., History of dementia and Parkinson's disease in 1st-degree relatives of patients with Alzheimer's disease, Neurology, 39 (1989) 1589-1592.

[12] Martin, J., Gheuens, J., Bruyland, M., Cras, P., Vandenberghe, A., Beyreuther, K., Masters, C., Dom, R., Ceuterick, C., Lübke, U., Van Heuverswijn, H., De Winter, G. and Van Broeckhoven, C., Farly-onset Alzheimer's disease in two large Belgian families, Neurology, 41 (1991) 62-68.

[13] Mastrogiacomo, F., Bergeron, C. and Kish, S.J., Brain $\alpha$ ketoglutarate dehydrogenase complex activity in Alzheimer's disease, J. Neurochem., 61 (1993) 2007-2014.

[14] McKhann, G., Drachman, D., Folstein, M., Katzman, R., Price, D. and Stadlan, E.M., Clinical diagnosis of Alzheimer's disease: a report of the NINCDS-ADRDA work group under the auspices of HHS Task Force on Alzheimer's disease, Neurology, 34 (1984) 939-945.

[15] Mitsunaga, Y., Takahashi, K., Tabira, T., Tasaki, H. and Watanabe, S., Assignment of a familial Alzheimer's disease locus between D14S289 and D14S53, Lancet, 344 (1994) 1154-1155.

[16] Mullan, M., Houlden, H., Windelspecht, M., Fidani, L., Lombardi, C., Diaz, P., Rossor, M., Crook, R., Hardy, J., Duff, K. and Crawford, F., A locus for familial early-onset Alzheimer's disease on the long arm of chromosome 14, proximal to the a1antichymotrypsin gene, Nature Genet., 2 (1992) 340-342.

[17] Nakano, K., Takase, C., Sakamoto, T., Nakagawa, S., Inazawa, J., Ohta, S. and Matuda, S., Isolation, characterization and structural organization of the gene and pseudogene for the dihydrolipoamide succinyltransferase component of the human 2oxoglutarate dehydrogenase complex, Eur. J. Biochem., 224 (1994) 179-189.

[18] Rogaev, E.I., Lukiw, W.J., Vaula, G., Haines, J.L., Rogaeva, E.A., Tsuda, T., Alexandrova, N., Liang, Y., Mortilla, M., Amaducci, L., Bergamini, L., Bruni, A.C., Foncin, J., Macciardi, F., Montesi, M.P., Sorbi, S., Rainero, I., Pinessi, L., Polinsky, R.J., Frommelt, P., Duara, R., Lopez, R., Pollen, D., Gusella, J.F., Tanzi, R., Crapper-McLachlan, D. and St George-Hyslop, P.H., Analysis of the $c$-fos gene on chromosome 14 and the promoter of the amyloid precursor protein gene in familial Alzheimer's disease, Neurology, 43 (1993) 2275-2279.

[19] Schellenberg, G.D., Bird, T.D., Wijsman, E.M., Orr, H.T., Anderson, L., Nemens, E., White, J.A., Bonnycastle, L., Weber, J.L., Alonso, M.E., Potter, H., Heston, L.L. and Martin, G.M., Genetic linkage evidence for a familial Alzheimer's disease locus on chromosome 14, Science, 258 (1992) 668-671. 
[20] Sheu, K.R., Cooper, A.J.L., Koike, K., Koike, M., Lindsay, J.G. and Blass. J.P., Abnormality of the $\alpha$-ketoglutarate dehydrogenase complex in fibroblasts from familial Alzheimer's disease, Ann. Neurol., 35 (1994) 312-318.

[21] St George-Hyslop, P., Haines, J., Rogaev, E., Mortilla, M., Vaula, G., Pericak-Vance, M., Foncin, J., Montesi, M., Bruni, A., Sorbi, S., Rainero, I., Pinessi, L., Pollen, D., Polinsky, R., Nee, L., Kennedy, J., Macciardi, F., Rogaeva, E., Liang, Y., Alexandrova, N., Lukiw, W., Schlumpf, K., Tanzi, R.E., Tsuda, T., Farrer, L., Cantu, J., Duara, R., Amaducci, L., Bergamini, L., Gusella, J., Roses, A. and Crapper-McLachlan, D., Genetic evidence for a novel familial Alzheimer's disease locus on chromosome 14, Nature Genet., 2 (1992) 330-334.
[22] Van Broeckhoven, C., Backhovens, H., Cruts, M., De Winter, G., Bruyland, M., Cras, P. and Martin, J., Mapping of a gene predisposing to early-onset Alzheimer's disease to chromosome 14q24.3, Nature Genet., 2 (1992) 335-339.

[23] van Duijn, C.M., Farrer, L.A., Backhovens, H., Cruts, M., Wehnert, A., Hofman, A. and Van Broeckhoven, C., A population-based study of familial Alzheimer's disease: linkage to chromosome 14, 19 and 21, Am. J. Hum. Genet., 55 (1994) 714 727.

[24] van Duijn, C.M., Hendriks, L., Cruts, M., Hardy, J.A., Hofman, A. and Van Broeckhoven, C., Amyloid precursor protein gene mutation in early-onset Alzheimer's disease, Lancet, 337 (1991) 978. 